\title{
Effects of the interannual variability of water column stratification on phytoplankton production and biomass in the northern zone off Baja California
}

\section{Efectos de la variabilidad interanual de la estratificación de la columna de agua sobre la producción y biomasa del fitoplancton en la zona norte frente a Baja California}

\author{
Eliana Gómez-Ocampo ${ }^{*}$, Reginaldo Durazo², Gilberto Gaxiola-Castro ${ }^{1 \dagger}$, Martín De la Cruz-Orozco1, \\ Ramón Sosa-Ávalos ${ }^{3}$ \\ ${ }^{1}$ Departamento de Oceanografía Biológica, Centro de Investigación Científica y de Educación Superior de \\ Ensenada, Carretera Tijuana-Ensenada, no. 3918, CP 22860, Ensenada, Baja California, México \\ ${ }^{2}$ Universidad Autónoma de Baja California, Facultad de Ciencias Marinas, Carretera Tijuana-Ensenada, \\ no. 3917, CP 22860, Ensenada, Baja California, 22860, México \\ ${ }^{3}$ Centro Universitario de Investigaciones Oceanológicas, Universidad de Colima, Carretera Manzanillo-Barra \\ de Navidad, km 20, CP 28860, Manzanillo, Colima, México \\ * Correspsonding author. E-mail: eliana.gomez@gmail.com.
}

\begin{abstract}
The ocean off the Baja California Peninsula (Mexico) has been affected by interannual processes. Some of these processes have produced changes in oceanic circulation and the atmosphere, which have been reflected in the structure of the water column. Stratification, defined as the amount of energy needed to mix water throughout the water column, determines nutrient availability in the euphotic zone for phytoplankton growth. The aim of this study is to describe and relate the interannual variations of phytoplankton production and biomass with changes in the structure of the water column. To this end, we analyzed time series (1997-2016) for integrated Chlorophyll $a$, integrated primary production, pycnocline depth, mixed layer depth, and stratification indices along line 100 of the Investigaciones Mexicanas de la Corriente de California (IMECOCAL) program. The results showed 2 periods of high stratification and a decrease in phytoplankton production and biomass off Baja California, corresponding to the intrusion of subarctic water and El Niño 2015-2016. Finally, by using generalized additive models, we related 2 photosynthethic parameters-maximum photosynthetic rate and maximum light utilization coefficient-with water stratification. These relationships explained interannual variations in phytoplankton production in terms of water column stratification. The time series and the analysis reported here for IMECOCAL line 100 could be used to extrapolate the effects of interannual physical processes on phytoplankton in other zones off the Baja California peninsula.
\end{abstract}

Key words: phytoplankton, stratification, primary production, Baja California, IMECOCAL

RESUMEN. El océano frente a las costas de la península de Baja California ha sido afectado por diferentes procesos interanuales. Algunos de estos procesos han generado cambios en la circulación oceánica y en la atmósfera que se han reflejado en la estratificación de la columna de agua. La estratificación, definida como la cantidad de energía necesaria para mezclar una columna de agua, determina la disponibilidad de nutrientes necesarios para el crecimiento del fitoplancton. El objetivo de este artículo es describir y relacionar las variaciones interanuales de la biomasa y producción del fitoplancton con la estructura de la columna de agua. Para esto, se analizaron las series de tiempo (1997-2016) de clorofila $a$ y producción primaria integradas, profundidad de la picnoclina y de la capa de mezcla y los índices de estratificación entre la superficie y los 100 y 200 m en la Línea 100 del programa Investigaciones Mexicanas de la Corriente de California (IMECOCAL). Los resultados mostraron que los periodos de mayor estratificación en la columna de agua fueron durante la intrusión de agua subártica 2002-2007 y El Niño 2015-2016, los cuales trajeron como consecuencia el mayor declive en la biomasa del fitoplancton (en ambos periodos) y de producción primaria (durante El Niño 2015-2016) en la zona norte frente a Baja California. Finalmente, se relacionaron la tasa fotosintética máxima y el coeficiente de utilización máxima de la luz, con el índice de estratificación por medio de modelos aditivos generalizados. Estas relaciones explicaron las variaciones interanuales en la producción primaria en correspondencia con la estratificación de la columna de agua. Las series de tiempo y el análisis presentado aquí para la línea 100 del IMECOCAL podrán ser extrapoladas a otras zonas frente a la península para entender la relación entre los procesos físicos con la biomasa y producción primaria del fitoplancton.

Palabras clave: fitoplancton, estratificación, producción primaria, Baja California, MECOCAL. 


\section{INTRODUCTION}

The ocean is a highly dynamic environment affected by a number of processes that take place at different spatial and temporal scales. The organisms that inhabit there are influenced by local processes, and these processes thus determine, to a great extent, the ecosystem's productivity at a regional level (Daly and Smith 1993). The ocean surface layer is home to marine phytoplankton, the primary component of the food chain. Being autotrophic organisms, their largest abundance occurs in the well-illuminated ocean layer known as the euphotic zone. Given the importance of light in photosynthesis, irradiance is one of the main factors that modulate phytoplankton abundance (Strickland 1965). However, phytoplankton growth and biomass are limited by nutrient availability in the euphotic zone. In this regard, processes at different temporal and spatial scales become important because they determine the structure of the water column, which is directly related to productivity.

One of the major factors limiting the distribution of phytoplankton is water column stratification. Stratification is defined as the amount of energy required to mix water throughout the water column (Simpson and Bowers 1981); if the latter is strongly stratified, more energy will be required to mix it relative to a less stratified column. Stratification of the water column determines the availability of nutrients that are used for phytoplankton growth. The mixed layer depth (MLD) and mixing intensity are physical parameters related to stratification that strongly affect phytoplankton primary production by determining the exposure of phytoplankton to light and its losses by sedimentation (Jäger et al. 2008). A deep MLD leads to a decrease in phytoplankton abundance because the population is distributed throughout a larger volume of water, that is, dilution (Behrenfeld and Boss 2014). In addition, if light conditions change as a result of vertical movements associated with turbulence (deep MLD), phytoplankton will photosynthesize in accordance to the amount of incident light in the MLD (Marra 1978).

The ocean region off the coast of the Baja California peninsula has been affected by interannual processes. Some of these processes have led to changes in ocean circulation, which in turn have modified the structure of the water column. For example, El Niño 1997-1998 produced a deepening of the pycnocline as a result of the influence of tropical warm water transported by a coastal flow parallel to the coast with a poleward direction (Durazo and Baumgartner 2002). During La Niña 1998-1999, intensification of coastal upwelling events led to increased phytoplankton biomass (Lavaniegos et al. 2002). From 2002 to 2006, the weakening of the Alaska Gyre caused the anomalous intrusion of subarctic water off Baja California (Durazo 2009), leading to a decrease in phytoplankton production and biomass (Gaxiola-Castro et al. 2008, Espinosa-Carreón et al. 2015). The ocean warming caused by “The warm Blob” during 2013 and 2014 and El Niño 2015-2016 produced the highest reduction of

\section{INTRODUCCIÓN}

El océano es un ambiente altamente dinámico y es afectado por diversos procesos que se desarrollan en diferentes escalas espaciotemporales. Los organismos que lo habitan están influenciados por los procesos que allí ocurren, los cuales determinan en gran parte la productividad de un ecosistema regional (Daly y Smith 1993). En la capa superficial del océano se encuentra el fitoplancton marino, que es el principal componente de la cadena trófica. Al ser organismos autótrofos, su mayor abundancia se presenta en la capa iluminada del océano conocida como zona eufótica. Debido a la importancia de la luz en la fotosíntesis, la irradiancia es uno de los principales factores que modulan la abundancia del fitoplancton (Strickland 1965). Sin embargo, el crecimiento y la biomasa del fitoplancton se ven limitados por la disponibilidad de los nutrientes en la zona eufótica. En este aspecto, los procesos que ocurren a diferentes escalas espaciotemporales son importantes porque determinan la estructura de la columna de agua, la cual está directamente ligada a la productividad.

Uno de los principales factores que limitan la distribución del fitoplancton es la estratificación de la columna de agua. La estratificación está definida como la cantidad de energía necesaria para mezclar una columna de agua (Simpson y Bowers 1981); si la columna de agua se encuentra fuertemente estratificada, necesitará de mayor energía para ser mezclada respecto a una con menor estratificación. La estratificación de la columna de agua determina la disponibilidad de nutrientes que son utilizados para el crecimiento del fitoplancton. La profundidad de la capa de mezcla (MLD, por sus siglas en inglés) y la intensidad de mezcla, son parámetros físicos relacionados con la estratificación que afectan fuertemente a la producción primaria del fitoplancton, al determinar la exposición del fitoplancton a la luz y su pérdida por sedimentación (Jäger et al. 2008). Una MLD profunda disminuye la abundancia de fitoplancton de manera que la población acumulada se distribuye a lo largo de un mayor volumen de agua, es decir, se encuentra más diluida (Behrenfeld y Boss 2014). Adicionalmente, si las condiciones de luz cambian como resultado de los movimientos verticales asociados con turbulencia (MLD profunda), el fitoplancton fotosintetizará de acuerdo con la cantidad de luz incidente dentro de la MLD (Marra 1978).

El océano frente a las costas de la península de Baja California se ha visto afectado por procesos interanuales. Algunos de estos procesos han generado cambios en la circulación oceánica, lo cual ha modificado la estructura de la columna de agua. Por ejemplo, el evento de El Niño 1997-1998 produjo una profundización en la picnoclina debido la influencia de agua cálida de origen tropical transportada por un flujo costero paralelo a la costa en dirección al polo (Durazo y Baumgartner 2002). Durante La Niña 1998-1999, la intensificación de las surgencias costeras permitió el incremento en la biomasa del fitoplancton 
phytoplankton biomass and production in the last 13 years at the southern boundary of the California Current (GómezOcampo et al. 2017). However, although phytoplankton production and biomass in this region have responded to these interannual processes, the mechanisms through which these events cause variations in the structure of the water column remain unknown.

Since 1997, the Investigaciones Mexicanas de la Corriente de California (Mexican Investigations on the California Current; IMECOCAL for its acronym in Spanish) program has surveyed the region off Baja California. This has allowed for better knowledge and understanding of the many oceanic physical, biological, and chemical processes in this region (Durazo and Baumgartner 2002, Lavaniegos et al. 2002, 2015; Espinosa-Carreon et al. 2004, Gaxiola-Castro et al. 2008, Gaxiola-Castro 2010, Jeronimo and Gomez-Valdes 2010, Martínez-Gaxiola et al. 2010, Durazo 2015, EspinosaCarreón et al. 2015, Martinez-Fuentes et al. 2016, GómezOcampo et al. 2017, Lavaniegos 2017). However, although there is available information on physical, biological, and chemical variables, there is still insufficient understanding on how physical processes influence the interannual changes in phytoplankton biomass and production in the water column.

The aim of this article is to describe and relate the interannual variations of phytoplankton biomass and production with changes in the structure of the water column. To this end, the 1997-2016 time series for chlorophyll $a$, primary production, pycnocline depth, and MLD were analyzed, as well as the stratification indices between the surface and 100 and $200 \mathrm{~m}\left(\Phi_{100}\right.$ and $\Phi_{200}$, respectively) along IMECOCAL line $100\left(\mathrm{~L} 100_{\mathrm{IMEC}}\right)$. $\mathrm{L} 100_{\mathrm{IMEC}}$ is one of the most intensively sampled lines and, due to its location, it has been found to be representative of the response of the marine ecosystem to interannual processes that occur off the peninsula (Linacre et al. 2010). In addition, in order to understand the relationship between interannual variations in the structure of the water column and phytoplankton production, the relationship between photosynthetic parameters (maximum photosynthetic rate at light saturation $\left[P_{m}^{B}\right]$ and the maximum light utilization coefficient $\left[\alpha^{B}\right]$ ), derived from photosynthesisirradiance experiments conducted at IMECOCAL sampling stations, is explored using stratification indices through generalized additive models (GAMs).

\section{MATERIAL AND METHODS}

\section{Data Sources}

In order to estimate the average conditions in the study area, data derived from remote sensing were obtained for sea surface temperature (SST), chlorophyll (CHL), and sea surface wind in the southern end of the California Current, off Baja California $\left(28^{\circ} \mathrm{N}-33^{\circ} \mathrm{N}, 120^{\circ} \mathrm{W}-114^{\circ} \mathrm{W}\right.$; Fig. 1). The monthly composite images (spatial resolution of $4 \times 4 \mathrm{~km}$ ) of SST and CHL concentrations derived from the MODIS-Aqua
(Lavaniegos et al. 2002). A partir de 2002 y hasta 2006, el debilitamiento del giro de Alaska causó la intrusión anómala de agua subártica en el océano frente a la península de Baja California (Durazo 2009), generando disminución en la producción y biomasa del fitoplancton (Gaxiola-Castro et al. 2008, Espinosa-Carreón et al. 2015). Recientemente se registró que durante el calentamiento del océano generado por el evento de "The Warm Blob" durante 2013 y 2014 y por El Niño 2015-2016 se produjo la reducción más alta de biomasa y producción del fitoplancton de los últimos 13 años en el límite sur de la corriente de California (Gómez-Ocampo et al. 2017). Sin embargo, aunque la producción y biomasa del fitoplancton en esta región han respondido a estos procesos interanuales, aún no se conoce la manera en que estos eventos ocasionan variaciones en la estructura de la columna de agua.

Desde 1997, el programa Investigaciones Mexicanas de la Corriente de California (IMECOCAL) ha realizado el monitoreo del océano frente a las costas de la península de Baja California. Esto ha permitido conocer y entender diversos procesos físicos, biológicos y químicos que ocurren en dicha región (Durazo y Baumgartner 2002, Lavaniegos et al. 2002, 2015; Espinosa-Carreon et al. 2004, Gaxiola-Castro et al. 2008, Gaxiola-Castro 2010, Jeronimo y Gomez-Valdes 2010, Martínez-Gaxiola et al. 2010, Durazo 2015, EspinosaCarreón et al. 2015, Martinez-Fuentes et al. 2016, GómezOcampo et al. 2017, Lavaniegos 2017). Sin embargo, aunque se tiene información de variables físicas, biológicas y químicas, aún falta entender cómo los procesos físicos influyen sobre los cambios interanuales de la biomasa y producción del fitoplancton en la columna de agua.

El objetivo de este artículo es describir y relacionar las variaciones interanuales de la biomasa y producción del fitoplancton con los cambios en la estructura de la columna de agua. Para esto, se analizaron las series de tiempo (1997-2016) de clorofila $a$, producción primaria, profundidad de la picnoclina y la MLD, así como los índices de estratificación entre la superficie y 100 y $200 \mathrm{~m}$ de profundidad ( $\Phi_{100}$ y $\Phi_{200}$, respectivamente) en la línea 100 del programa IMECOCAL ( $\left(100_{\text {IMEC }}\right.$ ). La L100 IMEC se ha caracterizado por ser una de las líneas del programa más muestreadas y se ha observado que, por su ubicación, es representativa de la respuesta del ecosistema marino a procesos interanuales que ocurren frente a la península (Linacre et al. 2010). Además, con el fin de entender la variación de la producción del fitoplancton con las variaciones interanuales en la estructura de la columna de agua, se presenta la relación entre los parámetros fotosintéticos (tasa fotosintética máxima a saturación de luz $\left[P_{m}^{B}\right]$ y coeficiente de máxima utilización de luz $\left.\left[\alpha^{B}\right]\right)$, generados a partir de experimentos de fotosíntesisirradiancia realizados en las estaciones de muestreo del IMECOCAL, y los índices de estratificación por medio de modelos aditivos generalizados (GAM, por sus siglas en inglés). 
sensor were downloaded from the ERDDAP database (http://coastwatch.pfeg.noaa.gov/erddap/index.html) for the 2003-2015 period. The primary production (PP) data obtained with the Behrenfeld and Falkowski (1997) Vertically Generalized Production Model (VGPM) was obtained from Oregon State University (OSU, http://www.science.oregonstate.edu/ocean.productivity/). The climatology for the mixed layer MLD, with a spatial resolution of $0.5^{\circ} \times 0.5^{\circ}$, was obtained from the Monthly Isopycnal and Mixed-layer Ocean Climatology (MIMOC, http://www.pmel.noaa.gov/ mimoc/) produced by the National Oceanic and Atmospheric Administration (NOAA). Wind data considered for this work were obtained from the National Centers for Environmental Prediction (NCEP). The zonal and southern components ( $0.25^{\circ}$ spatial resolution and 1-day temporal resolution) are available on NOAA's website at https://www.ncdc.noaa.gov. Wind stress curl was calculated from its components according to Trenberth et al. (1990). For all variables, long-period averages (hereafter average conditions) were calculated according to the length of the time period for which data was obtained. From the PP data obtained from OSU, average conditions were calculated for the northern zone off Baja California $\left(28^{\circ} \mathrm{N}-32^{\circ} \mathrm{N}\right)$ from 1998 to 2002 for data derived from the SeaWiFS sensor and from 2003 to 2016 for data obtained from the MODIS-Aqua sensor (both with a monthly resolution of $18 \times 18 \mathrm{~km})$. This climatology was subsequently used to estimate the anomalies from 1998 to 2016, which were defined as the observed value minus the calculated average.

The interannual variations in the structure of the water column and phytoplankton biomass in oceanic and coastal areas were analyzed using data from the stations located along $\mathrm{L} 100_{\text {IMEC }}$ (Fig. 1). This line was selected because it was the IMECOCAL line representative of the northern zone off Baja California with the largest number of temperature, salinity, and chlorophyll $a$ (Chla) records from 1998 to 2016. Cruise averages were calculated for the variables analyzed at the $\mathrm{L} 100_{\text {IMEC }}$ stations representative of the coastal zone (stations 30 and 35) and the oceanic zone (stations 45, 50, 40, 55, and 60) (Gaxiola-Castro et al. 2010, Durazo 2015). Phytoplankton Chla samples were obtained from water samples collected with Niskin bottles at standard depths $(0,10,20,50$, and $100 \mathrm{~m}$ ) and analyzed with the fluorimetric method (Yentsch and Menzel 1963, Holm-Hansen et al. 1965). Temperature and salinity CTD (Sea-Bird) data were used to estimate MLD following the method proposed by Kara et al. (2000) and modified by Jeronimo and Gomez-Valdes (2010) for the IMECOCAL zone. Pycnocline depth $\left(Z_{P y c}\right)$ was calculated according to Fiedler et al. (2013). The stratification parameter $(\Phi)$ between the surface and $100 \mathrm{~m}$ and the surface and $200 \mathrm{~m}$ depth ( $\Phi_{100}$ and $\Phi_{200}$, respectively) was calculated according to Simpson and Bowers (1981). Chla was integrated into the water column from the surface to $100 \mathrm{~m}$ depth using the trapezoidal rule to estimate integrated Chla $\left(\right.$ Chl $\left.a_{\mathrm{int}}, \mathrm{mg} \cdot \mathrm{m}^{-2}\right)$.

\section{MATERIALES Y MÉTODOS}

\section{Fuentes de datos}

Con el fin de representar las condiciones medias del área de estudio, se obtuvieron datos derivados de sensores remotos de temperatura superficial del mar (TSM), clorofila (CHL) y viento sobre la superficie del océano en el límite sur de la corriente de California, frente a Baja California $\left(28^{\circ} \mathrm{N}-33^{\circ} \mathrm{N}, 120^{\circ} \mathrm{W}-114^{\circ} \mathrm{W}\right.$; Fig. 1). Las imágenes de los compuestos mensuales (resolución espacial de $4 \times 4 \mathrm{~km}$ ) de TSM y (CHL) derivados del sensor MODIS-Aqua fueron descargadas de la base de datos ERDDAP (http://coastwatch.pfeg.noaa.gov/erddap/index.html) para el periodo 2003-2016. Los datos de producción primaria (PP) obtenidos con el Modelo se Producción Verticalmente Generalizado (Vertically Generalized Production Model, VGPM) de Behrenfeld y Falkowski (1997) fueron adquiridos de la Universidad Estatal de Oregón (OSU, http://www.science.oregonstate.edu/ocean.productivity/). La climatología de la MLD, con una resolución espacial de $0.5^{\circ} \times 0.5^{\circ}$, fue obtenida del Monthly Isopycnal and Mixed-layer Ocean Climatology (MIMOC, http://www.pmel.noaa.gov/mimoc/) de la Oficina Nacional de Administración Oceánica y Atmosférica (NOAA). Los datos de viento considerados para este trabajo fueron obtenidos de Centros Nacionales para la Predicción Ambiental (NCEP, por sus siglas en inglés). Las componentes zonal y meridional (resolución espacial de $0.25^{\circ}$ y resolución temporal de un día) están disponibles en la plataforma de la NOAA en https://www.ncdc.noaa.gov. El rotacional del esfuerzo del viento se calculó a partir de sus componentes según Trenberth et al. (1990). Para todas las variables, se calcularon los promedios de largo periodo (de aquí en adelante llamadas condiciones medias) según la extensión del periodo para el cual los datos fueron obtenidos. Para los datos de PP obtenidos de la OSU, se calcularon las condiciones medias en la zona norte frente a Baja California $\left(28^{\circ} \mathrm{N}-32^{\circ} \mathrm{N}\right)$ de 1998 a 2002 para la PP derivada del sensor SeaWiFS y de 2003 a 2016 para la PP derivada del MODIS-Aqua (ambas con resolución mensual de $18 \times 18 \mathrm{~km}$ ). Esta climatología se utilizó posteriormente para estimar las anomalías de 1998 a 2016, las cuales se definieron como el valor observado menos el promedio calculado.

Con el fin de analizar la variación interanual de la estructura de la columna de agua y de la biomasa del fitoplancton en las zonas costera y oceánica, se seleccionaron las estaciones que conforman la L100 IMEC (Fig. 1). El criterio de elección se basó en tomar una línea IMECOCAL representativa de la zona norte frente a Baja California que tuviera el mayor número de mediciones de temperatura, salinidad y clorofila $a$ (Chla) desde 1998 hasta 2016. Se calcularon los promedios por crucero de las variables analizadas en estaciones de la L100 ${ }_{\text {IMEC }}$ representativas de la zona costera (estaciones $30 \mathrm{y}$ 35) y de la zona oceánica (estaciones 40, 45, 50, 55 y 60) (Gaxiola-Castro et al. 2010, Durazo 2015). Las muestras de 

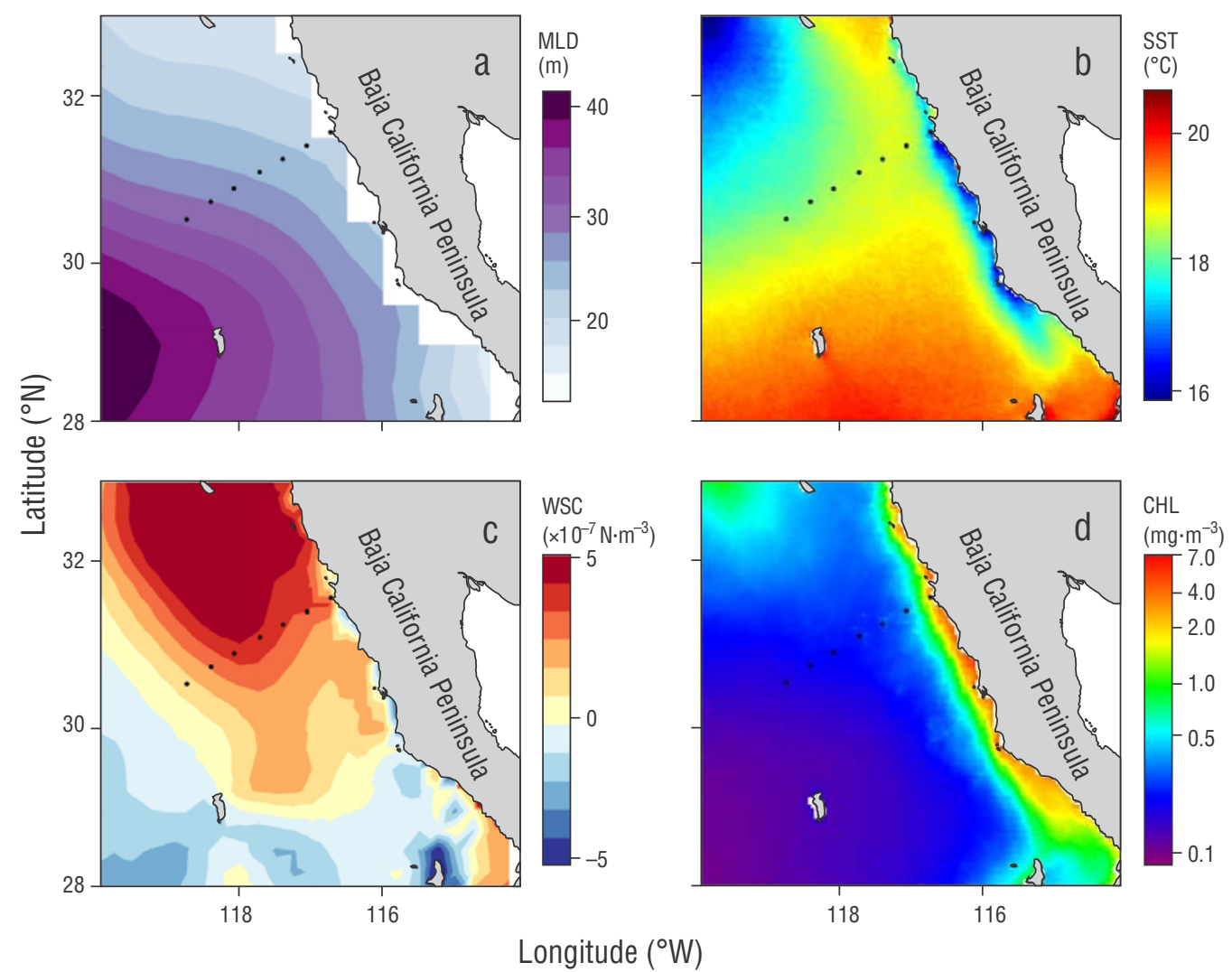

Figure 1. Horizontal distribution of the mean conditions for (a) mixed layer depth (MLD) (b) sea surface temperature (SST), (c) wind stress curl (WSC), and (d) satellite chlorophyll (CHL). Dots indicate the location of the hydrographic stations where in-situ data were collected along line 100 of the Investigaciones Mexicanas de la Corriente de California (IMECOCAL) program.

Figura 1. Distribución horizontal de las condiciones medias para (a) profundidad de la capa de mezcla (MLD), (b) temperatura superficial del mar (SST), (c) rotacional del esfuerzo del viento (WSC) y (d) clorofila de satélite (CHL). Los puntos indican la ubicación de las estaciones hidrográficas donde los datos in situ fueron recolectados a lo largo de la línea 100 del programa Investigaciones Mexicanas de la Corriente de California (IMECOCAL).

The photosynthesis-irradiance experiments (P-I curves) were carried out onboard during some oceanographic campaigns at oceanic stations, with water samples collected between 10:00 and 14:00, local time, at a depth corresponding to $30 \%$ surface irradiance. Water was collected with 5-L Niskin bottles to fill 27 flat 250-mL polystyrene bottles (Nucleon), which were spiked with $100 \mu \mathrm{L} \mathrm{NaH}^{14} \mathrm{CO}_{3}$ $(\sim 5 \mu \mathrm{Ci}$ ). Bottles were placed in a Morel incubator (Marcel et al. 1994) for $\sim 2 \mathrm{~h}$ under a light gradient of 1 to $900 \mu \mathrm{mol} \cdot$ quanta $\cdot \mathrm{m}^{-2} \cdot \mathrm{s}^{-1}$ generated by a $500 \mathrm{~W}$ tungsten halogen lamp. Carbon assimilation rate $\left(P, \mathrm{mg} \mathrm{C} \cdot \mathrm{m}^{-3} \cdot \mathrm{h}^{-1}\right)$ was estimated from the incorporation of ${ }^{14} \mathrm{C}$ during incubation, by subtracting the baseline values (time $=0$ ), and was normalized with respect to Chla values measured at a depth of $30 \%$ surface irradiance in each experiment $\left(P^{B}\right.$, mg C. [mg Chla h] $\left.]^{-1}\right)$. The $\alpha^{B}\left(\mathrm{mg} \mathrm{C} \cdot[\mathrm{mg} \mathrm{Chl} a \cdot \mathrm{h}]^{-1} \cdot[\mu \mathrm{mol} \cdot\right.$ quanta $\left.\mathrm{m}^{-2} \cdot \mathrm{h}^{-1}\right]^{-1}$ ) and $P_{m}^{B} \quad\left(\mathrm{mg} \mathrm{C} \cdot[\mathrm{mg} \mathrm{Chl} a \cdot \mathrm{h}]^{-1}\right.$ ) parameters were calculated with the hyperbolic function described by Jassby and Platt (1976): $P^{B}=P_{m}^{B} \tanh \left(E_{L} \alpha^{B} / P_{m}^{B}\right)$, where $E_{L}$ is the irradiance of the tungsten halogen lamp measured from the
Chla del fitoplancton fueron obtenidas a partir de muestras de agua recolectadas con botellas Niskin a profundidades estándar $(0,10,20,50$ y $100 \mathrm{~m})$ y analizadas con el método fluorimétrico (Yentsch y Menzel 1963, Holm-Hansen et al. 1965). A partir de datos de temperatura y salinidad obtenidos con un CTD Sea-Bird, se estimó la MLD siguiendo el método propuesto por Kara et al. (2000) y modificado por Jeronimo y Gomez-Valdes (2010) para la zona IMECOCAL. La profundidad de la picnoclina $\left(Z_{P y c}\right)$ fue calculada según Fiedler et al. (2013). El parámetro de estratificación $(\Phi)$ en los primeros 100 y $200 \mathrm{~m}$ de la columna de agua $\left(\Phi_{100}\right.$ y $\Phi_{200}$, respectivamente) fue calculado según Simpson y Bowers (1981). La Chla fue integrada en la columna de agua desde la superficie hasta $100 \mathrm{~m}$ de profundidad mediante la regla del trapecio para obtener la clorofila integrada $\left(\mathrm{Chl}_{\mathrm{in}}, \mathrm{mg} \cdot \mathrm{m}^{-2}\right)$.

Los experimentos fotosíntesis-irradiancia (curvas P-E) se realizaron a bordo en las estaciones oceánicas de algunas campañas oceanográficas, con muestras de agua recolectadas entre las 10:00 y las 14:00, tiempo local, en la profundidad correspondiente al 30\% de irradiancia superficial. El agua fue 
inside of each bottle in the incubator with a QSL 100 (Biospherical Instruments). In order to represent the interannual variation in photosynthetic parameters in the northern zone off Baja California and given the scarcity of the P-I experi-

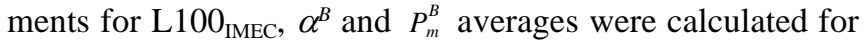
the stations of IMECOCAL lines 100, 103, 110, and 113. The criterion for using this average stems from the fact that the variability in the physical and biological conditions in the region north of Vizcaíno Bay $\left(28^{\circ} \mathrm{N}\right)$ is spatially homogeneous in response to the different temporal scales (GaxiolaCastro et al. 2010, Durazo 2015). Therefore, phytoplankton communities in this area would be expected to be similar. The information on the methods and equipment used during the IMECOCAL cruises is detailed in http://imecocal.cicese.mx/.

\section{Statistical analysis}

The relationship of trends PP and water column structure was explored using GAMs (Hastie and Tibshirani 1986). This method fits non-linear relationships between variables, which are expressed as a curve from a smoothed function. In contrast with linear models, GAMs allow assigning an exponential distribution (Poisson, binomial, gamma, or normal) to the dependent variable.

In order to explain the variation in PP in terms of phytoplankton physiology, the $\alpha^{B}$ and $P_{m}^{B}$ parameters were related to structure of the water column represented by $\Phi_{100}$. To obtain a more robust statistical fit, P-I experiments carried out between 1998 and 2013 were used (no experiments were conducted in 2014 and 2016) at different stations of the IMECOCAL lines $(n=273)$. The relationships were fitted with the $\mathrm{R}$ program for statistical calculations using the "mixed GAM computation vehicle" (mgcv) package (Wood et al. 2015). The mgcv package sets curve functions to the terms of the model and makes a cross-validation to determine the optimal smoothing degree (i.e., degrees of freedom) (Wood 2006). The best distribution was assigned to the predictor variables $\alpha^{B}$ and $P_{m}^{B}$ using the $\chi$-square goodness-of-fit test.

\section{RESUlts}

\section{Average conditions in the study area}

In order to characterize the horizontal distribution of some variables related to water column structure and productivity off Baja California, average conditions in the study area were obtained for MLD, SST, wind stress curl, and surface chlorophyll (Fig. 1). Average MLD and SST show higher values offshore and in the oceanic area to the south of the Baja California peninsula (Fig. 1a, b). In contrast, average wind stress curl and chlorophyll values derived from satellite imagery were higher in the coastal zone and decreased offshore and to the south of the peninsula (Fig. 1c, d). Therefore, 2 typical average conditions were observed in the study area. recolectada con botellas Niskin de $5 \mathrm{~L}$ de capacidad para llenar 27 botellas planas de poliestireno de $250 \mathrm{~mL}$ (Nucleon), las cuales se inocularon con $100 \mu \mathrm{L}$ de $\mathrm{NaH}_{14} \mathrm{CO}_{3}(\sim 5 \mu \mathrm{Ci})$. Las botellas fueron colocadas en un incubador tipo Morel (Marcel et al. 1994) por $\sim 2 \mathrm{~h}$ en un gradiente de luz de $1 \mathrm{a}$ $900 \mu \mathrm{mol} \cdot$ cuanta $\mathrm{m}^{-2} \cdot \mathrm{s}^{-1}$ generado por una lámpara de tungsteno-halógeno de $500 \mathrm{~W}$. La tasa de asimilación de carbono $\left(P, \mathrm{mgC} \cdot \mathrm{m}^{-3} \cdot \mathrm{h}^{-1}\right)$ se obtuvo a partir de la incorporación de ${ }^{14} \mathrm{C}$ durante la incubación, sustrayendo los valores de tiempo cero, y se normalizó con respecto a la Chla medida a la profundidad del $30 \%$ de irradiancia superficial en cada experimento $\left(P^{B}\right.$, mg C $\left.\cdot[\mathrm{mg} \mathrm{Chl} a \cdot h]^{-1}\right)$. Los parámetros $\alpha^{B}$ $\left(\mathrm{mgC} \cdot[\mathrm{mg} \mathrm{Chl} a \cdot \mathrm{h}]^{-1} \cdot\left[\mu \mathrm{mol} \text { cuanta } \cdot \mathrm{m}^{-2} \cdot \mathrm{h}^{-1}\right]^{-1}\right)$ y $P_{m}^{B}(\mathrm{mgC} \cdot$ [mg Chla $\cdot \mathrm{h}]^{-1}$ ) fueron calculados con la función hiperbólica descrita por Jassby y Platt (1976): $P^{B}=P_{m}^{B} \tanh \left(E_{L} \alpha^{B} / P_{m}^{B}\right)$, donde $E_{L}$ es la irradiancia de la lámpara de tungstenohalógeno medida en el interior de cada botella en el incubador, con un QSL 100 de Biospherical Instruments. Con el fin de representar la variación interanual en los parámetros fotosintéticos en la zona norte frente a Baja California y debido a la escasez de experimentos P-E en la L100 ${ }_{\mathrm{IMEC}}$, se calcularon los promedios de $\alpha^{B}$ y $P_{m}^{B}$, para las estaciones de las líneas 100, 103, 110 y 113 del IMECOCAL. El criterio para realizar este promedio se basó en que se ha reportado que la variabilidad de las condiciones físicas y biológicas en la región al norte de bahía Vizcaíno $\left(28^{\circ} \mathrm{N}\right)$ son espacialmente homogéneas en respuesta a las diferentes escalas temporales (Gaxiola-Castro et al. 2010, Durazo 2015). Por lo tanto, se esperaría que las comunidades de fitoplancton presentes en esta zona sean similares. La información de los métodos y equipos usados en los cruceros del programa IMECOCAL se encuentra detallada en http://imecocal.cicese.mx/.

\section{Análisis estadístico}

Para encontrar la relación entre las tendencias de los valores de PP y la estructura de la columna de agua, se usaron los modelos GAM (Hastie y Tibshirani 1986). Este método ajusta relaciones no-lineales entre las variables, las cuales son expresadas como una curva resultante de una función suavizada. En contraste con los modelos lineales, los GAM permiten asignar una distribución de la familia de las exponenciales (Poisson, binomial, gamma, o distribución normal) a la variable dependiente.

Con el fin de explicar la variación en la PP en términos de la fisiología del fitoplancton, los parámetros $\alpha^{B}$ y $P_{m}^{B}$ fueron relacionados con la estructura de la columna de agua representada por $\Phi_{100}$. Para obtener un ajuste estadístico más robusto, se usaron experimentos P-E llevados a cabo entre 1998-2013 (no hubo experimentos en 2014 y 2016) en diferentes estaciones de las líneas del programa IMECOCAL $(n=273)$. Las relaciones fueron ajustadas con el programa $\mathrm{R}$ para cálculos estadísticos usando el paquete "mixed GAM computation vehicle" (mgcv) (Wood et al. 2015). El paquete $m g c v$ ajusta funciones de curvas a los términos del modelo y 
The first occurs in the coastal area and off the northern part of the peninsula, and seems to be more dynamic according to the wind stress curl values; consequently, the water column is expected to be less stratified. The second, which is less dynamic, occurs mainly in the oceanic area and off the southern part of the peninsula, with conditions typical of a more stratified environment.

\section{7-2016 time series in $\mathrm{L}_{100}{ }_{\text {IMEC }}$}

The effect of the interannual variability in water column structure on phytoplankton was characterized from time series of the variables of interest in the $\mathrm{L} 100_{\text {IMEC }}$ coastal and oceanic areas. Particular periods during which the Chl $a_{\text {int }}$ signal showed obvious variations were selected (Fig. 2a). These periods correspond to the period from 2002 to 2006 (anomalous intrusion of subarctic water), La Niña 2008, and the ocean warming during 2013 to 2016 resulting from "The warm Blob” and El Niño 2015-2016.

The time series of the annual Chl $a_{\text {int }}$ average showed a clear response to interannual events in coastal and oceanic areas (Fig. 2a). The lowest Chl $a_{\text {int }}$ values $\left(<40 \mathrm{mg} \mathrm{m}^{-2}\right)$ in the coastal and oceanic areas occurred between 2002 and 2007. In contrast, La Niña 2008 was associated with the maximum Chl $a_{\text {int }}$ values of the time series in both areas, with similar values in the coastal $\left(\sim 76 \mathrm{mg} \cdot \mathrm{m}^{-2}\right)$ and oceanic $\left(\sim 75 \mathrm{mg} \cdot \mathrm{m}^{-2}\right)$ areas. From 2008 to late 2016 there was a decline in Chl $a_{\text {int }}$ values in the oceanic area, reaching minimum values as low as $\sim 30 \mathrm{mg} \cdot \mathrm{m}^{-2}$ but slightly higher compared to those observed during the subarctic water intrusion (2002 to 2006). In 2013 Chla $a_{\text {int }}$ remained relatively unchanged until 2015, when it increased. In the coastal area the lowest Chl $a_{\text {int }}$ values were recorded between 2011 and 2014 and were similar to those observed during the subarctic water intrusion. In this area, Chl $a_{\text {int }}$ increased in 2014 until reaching $\sim 45 \mathrm{mg} \cdot \mathrm{m}^{-2}$ in 2016.

Phytoplankton production in the northern zone off Baja California showed periods with increasing and decreasing values through the time series (Fig. 2b). During the intrusion of subarctic water, no definite trend was observed. However, conditions during La Niña 2008 led to a rise in PP rates. Afterwards, due to the "The warm Blob” effect during 2014, phytoplankton production dropped and attained even lower levels during El Niño 2015-2016.

MLD was deeper in the oceanic than in the coastal area, but variation was similar in both areas from 1998 to 2016 (Fig. 2c). Aspects worth noting are the reduction in the thickness of the mixing layer during the subarctic water intrusion and the particularly noticeable deepening in the oceanic area in 2004. A period of shallow MLD also took place during La Niña 2008, reaching a minimum value in 2011 in the coastal and oceanic areas (12 and $25 \mathrm{~m}$, respectively). However, the most superficial MLD values in both areas occurred from 2010 to 2012, after which the mixed layer became deeper in hace validación-cruzada para determinar el grado óptimo de suavizado (i.e., grados de libertad) (Wood 2006). Se asignó la mejor distribución a las variables predictoras $\alpha^{B}$ y $P_{m}^{B}$ usando la prueba de bondad de ajuste $\chi$ cuadrada.

\section{RESUltados}

\section{Condiciones promedio del área de estudio}

Con el fin de caracterizar la distribución horizontal de algunas variables relacionadas con la estructura de la columna de agua y la productividad frente a Baja California, se obtuvieron las condiciones promedio en el área de estudio para la MLD, TSM, rotacional del esfuerzo del viento y clorofila superficial (Fig. 1). Las condiciones promedio de la MLD y la TSM presentan valores más altos hacia afuera de la zona costera y en la zona oceánica hacia el sur de la península de Baja California (Fig. 1a, b). Contrario a lo anterior, los valores promedio del rotacional del esfuerzo del viento y de clorofila derivada de satélite son más altos en la zona costera y disminuyen hacia mar abierto y hacia el sur de la península (Fig. 1c, d). Por lo tanto, en el área de estudio se observó que ocurren 2 condiciones promedio típicas. La primera ocurre en la zona costera y frente al norte de la península, que según los valores del rotacional del esfuerzo de viento parece ser más dinámica y, por ende, se espera que la columna de agua sea menos estratificada. La segunda, menos dinámica, ocurre principalmente en la zona oceánica y frente al sur de la península e implica condiciones típicas de un ambiente más estratificado.

\section{Series de tiempo 1997-2016 en la L100 IMEC $_{\text {IME }}$}

El efecto de la variabilidad interanual de la estructura de la columna de agua sobre el fitoplancton se caracterizó a partir de las series de tiempo de variables de interés en las regio-

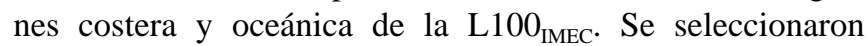
periodos particulares en los que la señal de la Chl $a_{\text {int }}$ mostró cambios evidentes (Fig. 2a). Estos corresponden al periodo desde 2002 hasta 2006 (intrusión anómala de agua subártica), al evento de La Niña 2008 y al calentamiento del océano durante 2013 a 2016 generado por “The Warm Blob” y El Niño 2015-2016.

En la serie de tiempo del promedio anual de Chl $a_{\text {int }}$ se observó una respuesta clara a los eventos interanuales en las zonas costera y oceánica (Fig. 2a). Entre 2002 y 2007, los valores de Chl $a_{\text {int }}$ en la zona costera y oceánica fueron los más bajos ( $<40 \mathrm{mg} \cdot \mathrm{m}^{-2}$ ) de la serie de tiempo. Contrario a esto, durante La Niña 2008 se observaron los máximos de Chl $a_{\text {int }}$ de la serie de tiempo en ambas zonas, con valores similares en la zona costera $\left(\sim 76 \mathrm{mg} \cdot \mathrm{m}^{-2}\right)$ y en la zona oceánica $\left(\sim 75 \mathrm{mg} \cdot \mathrm{m}^{-2}\right)$. Desde 2008 y hasta finales de 2016 ocurrió un declive en la Chl $a_{\text {int }}$ en la zona oceánica que alcanzó valores mínimos de hasta $\sim 30 \mathrm{mg} \cdot \mathrm{m}^{-2}$, pero ligera- 

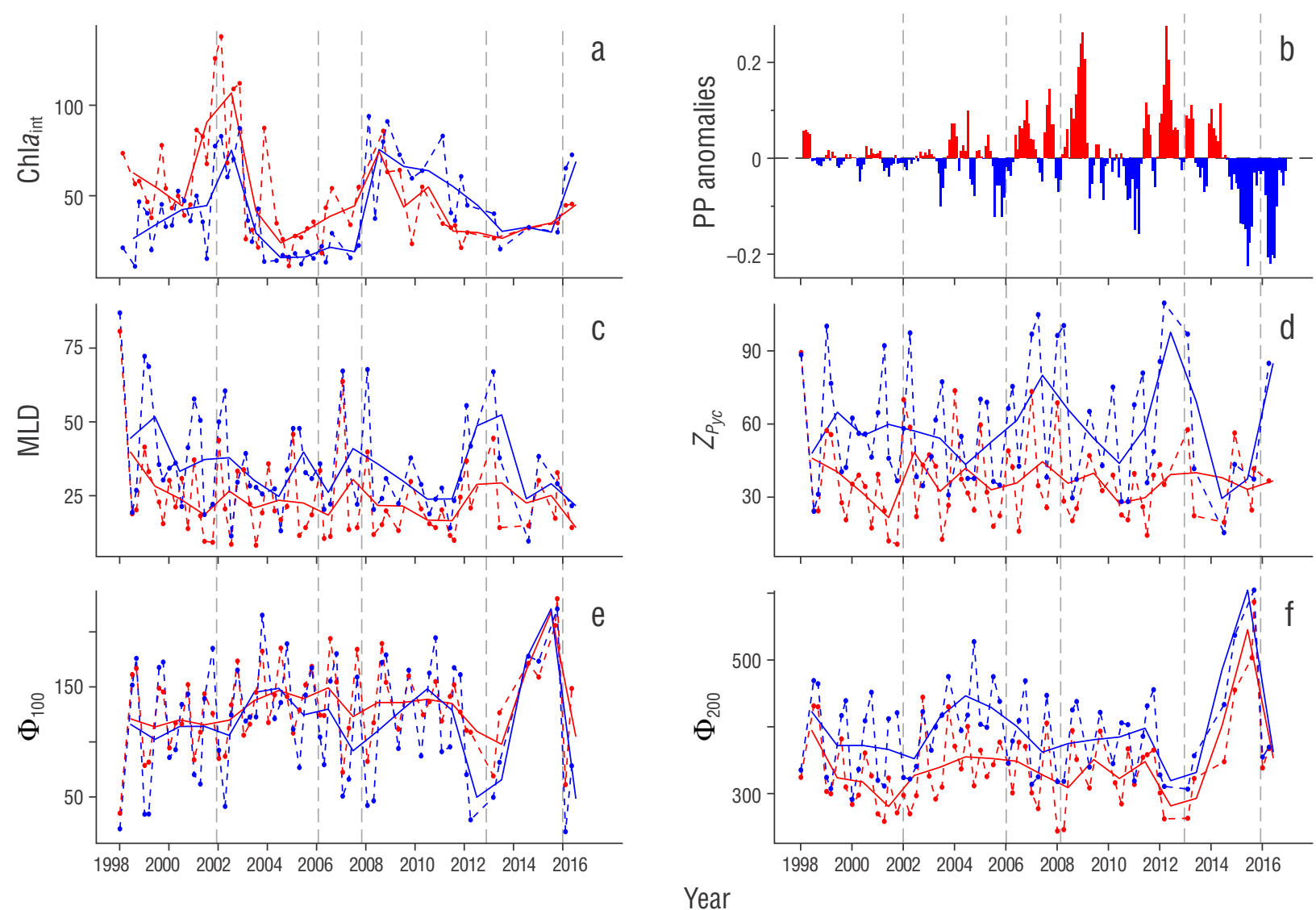

Figure 2. Time series (1998-2016) for (a) water-column integrated chlorophyll $a\left(\mathrm{Chl}_{\mathrm{int}}, \mathrm{mg} \cdot \mathrm{m}^{-2}\right)$, (b) primary production (PP, g C $\left.\cdot \mathrm{m}^{-2} \cdot \mathrm{d}^{-1}\right)$ anomalies obtained from SeaWiFS (1998-2002) and MODIS-Aqua (2003-2016) sensors, (c) mixed layer depth (MLD, m), (d) pycnocline depth $\left(Z_{P y c}, \mathrm{~m}\right)$, and water column stratification parameter at (e) 100 and (f) $200 \mathrm{~m}$ depth ( $\Phi_{100}$ and $\Phi_{200}$, respectively; Joules) along IMECOCAL line 100. Colors indicate the time series for coastal (red) and oceanic (blue) stations. Dashed color lines denote the monthly mean and solid color lines represent the yearly mean. Gray dashed lines indicate the periods selected for the analysis..

Figura 2. Serie de tiempo (1998-2016) para (a) clorofila $a$ integrada en la columna de agua (Chl $a_{\text {int }}$ mg· $\mathrm{m}^{-2}$ ), (b) anomalías de la producción primaria (PP, g C $\cdot \mathrm{m}^{-2} \cdot \mathrm{d}^{-1}$ ) obtenidas de los sensores SeaWiFS (1998-2002) y MODIS-Aqua (2003-2016), (c) profundidad de la capa de mezcla ( MLD, m), (d) profundidad de la picnoclina $\left(Z_{P y c}, \mathrm{~m}\right)$ y parámetro de estratificación de la columna de agua a (e) 100 y (f) $200 \mathrm{~m}$ de profundidad ( $\Phi_{100}$ and $\Phi_{200}$, respectivamente; Joules) a lo largo de la línea 100 del IMECOCAL. Los colores indican la serie de tiempo para estaciones costeras (rojo) y oceánicas (azul). Las líneas punteadas de color denotan las medias mensuales y las líneas de color sólidas indican las medias anuales. Las líneas grises punteadas indican los periodos seleccionados para el análisis.

the oceanic area until reaching a maximum depth of $\sim 50 \mathrm{~m}$ in 2013 under the influence of “The warm Blob”.

Pycnocline depth $\left(Z_{P y c}\right)$ was more variable in the oceanic than in the coastal area (Fig. 2d). In 2004, during the subarctic water intrusion, there was a slight reduction in $Z_{p y c}$ in the oceanic area $(\sim 40 \mathrm{~m})$. The same behavior was observed during 2010, when $Z_{P y c}$ reached its lowest in both areas ( 30 and $45 \mathrm{~m}$ in the coastal and oceanic areas, respectively). However, the deepest $Z_{P y c}$ value ( $90 \mathrm{~m}$ ) was recorded in the oceanic area in 2012, prior to "The warm Blob”. From that year, the pycnocline in this zone became shallower and reached the value closest to the surface in 2014 ( 30 m). Subsequently, with the onset of El Niño, $Z_{P y c}$ deepened in 2015 and reached its maximum value in 2016, with a value similar to the one observed in 2007 ( 80 m, first peak in the mente más altos respecto a aquellos observados durante la intrusión de agua subártica (2002 a 2006). En 2013 no se observó variación significativa en la Chl $a_{\text {int }}$ hasta 2015, cuando incrementó. En la zona costera, los valores más bajos de Chl $a_{\text {int }}$ ocurrieron entre 2011 y 2014 y fueron similares a los observados durante la intrusión del agua subártica. En esta zona, a partir de 2014, la Chl $a_{\text {int }}$ se incrementó hasta llegar a un valor de $\sim 45 \mathrm{mg} \cdot \mathrm{m}^{-2}$ en 2016 .

La producción del fitoplancton en la zona norte frente a Baja California mostró periodos de aumento y disminución a lo largo de la serie de tiempo (Fig. 2b). Durante la intrusión de agua subártica, no se observó una tendencia definida. Sin embargo, las condiciones durante La Niña 2008 generaron el aumento en las tasas de PP. Enseguida, debido al efecto de “The Warm Blob” durante 2014, se redujo la producción del 
time series). Although variations were not as marked in the coastal area as in the oceanic area, an aspect worth noting is the slight deepening of the pycnocline during the subarctic water intrusion in 2002 and from 2012 to 2016, under the influence of “The warm Blob” and El Niño.

The stratification indices $\Phi_{100}$ and $\Phi_{200}$ showed a similar variation in both areas (Fig. 2e, f). The time series for both indices reveal an increase in the stratification of the water column during the intrusion of subarctic water (up to $\Phi_{100} \sim$ $150 \mathrm{~J} \cdot \mathrm{m}^{-3}$ in both areas, and $\Phi_{200} \sim 450 \mathrm{~J} \cdot \mathrm{m}^{-3}$ and $\Phi_{200} \sim$ $350 \mathrm{~J} \cdot \mathrm{m}^{-3}$ in the oceanic and coastal areas, respectively) and the peak observed in 2015 after the "The warm Blob" and the onset of El Niño 2015-2016 $\left(\Phi_{100} \sim 225 \mathrm{~J} \cdot \mathrm{m}^{-3}\right.$ and $\Phi_{200}>$ $500 \mathrm{~J} \cdot \mathrm{m}^{-3}$ in both areas).

\section{DISCUSSION}

Of all the variables analyzed, phytoplankton biomass was the one that best projected the interannual variability due to the various events that influenced the ocean off the northern part of Baja California. Our hypothesis is that highstratification periods can reduce phytoplankton biomass and affect phytoplankton photophysiology (decreased $\alpha^{B}$, increased $P_{m}^{B}$ ), and these changes are in turn reflected in the variations in $\mathrm{PP}$.

Stratification was associated with decreasing and increasing phytoplankton production and biomass during the intrusion of subarctic water, La Niña 2008, and the ocean warming caused by "The warm Blob" and El Niño 2015-2016. A marked water column stratification was observed during the warm periods and the intrusion of subarctic water, coupled with the reduction in MLD and $Z_{P y c}$. In a poorly mixed water column, phytoplankton can remain in the upper, well-illuminated layer during sufficient time to maintain a population (Huisman 1999). In contrast, when the water column is well mixed, phytoplankton is transported throughout it and, in time, each microorganism experiences the depth-averaged light intensity, which decreases according to MLD. As a result, the depth-averaged specific PP drops as the depth of the water column increases (Huisman 1999, Diehl et al. 2002). In addition, MLD and mixing intensity are related to the accumulation of biomass through the losses of phytoplanktonic cells by sedimentation (Jäger et al. 2008). The probability that a phytoplanktonic organism or a colony sinks below the euphotic zone decreases as mixing intensity increases (Huisman et al. 2004). This occurs because turbulent mixing disperses phytoplankton throughout the water column, which partially offsets sedimentation. In general, losses by sinking affect primarily organisms that sink rapidly (e.g., diatoms) in shallow and poorly mixed water columns (Diehl et al. 2002). In summary, a poorly mixed water column (high stratification) favors PP rates but restrains the accumulation of biomass, as observed in the period of subarctic water intrusion between 2003 and 2005 and during “The warm Blob” in 2013-2014 (Fig. 2). fitoplancton, la cual llegó a ser más baja durante El Niño 2015-2016.

La MLD fue más profunda en la zona oceánica, pero presentó una variación similar en ambas zonas desde 1998 hasta 2016 (Fig. 2c). Destacan la reducción del espesor de la capa de mezcla durante la intrusión de agua subártica y la profundización particularmente notoria en 2004 en la zona oceánica. Durante el evento de La Niña 2008 también hubo un periodo de disminución en la MLD, la cual llegó a un valor mínimo en 2011 en las zonas costera y oceánica (12 y $25 \mathrm{~m}$, respectivamente). Sin embargo, los valores de MLD más superficiales en ambas zonas ocurrieron desde 2010 hasta 2012; a partir de este último año la capa de mezcla se profundizó en la zona oceánica hasta alcanzar un máximo de 50 m en 2013 bajo la influencia de "The Warm Blob".

La profundidad de la picnoclina $\left(Z_{P y c}\right)$ fue más variable en la zona oceánica que en la zona costera (Fig. 2d). En 2004, durante la intrusión de agua subártica, se observó una ligera reducción de la $Z_{P y c}$ en la zona oceánica $(\sim 40 \mathrm{~m})$. El mismo comportamiento se observó durante La Niña 2008, cuando la profundidad de la picnoclina llegó a su valor más bajo durante 2010 en ambas zonas ( 30 y $45 \mathrm{~m}$ en las zona costera y oceánica, respectivamente). Sin embargo, durante 2012 se presentó en la zona oceánica la $Z_{P y c}$ más honda ( 90 m), antes de la ocurrencia de "The Warm Blob". A partir de este año, la picnoclina en esta zona redujo su profundidad y alcanzó el valor más cercano a la superficie durante 2014 ( 30 m). Posteriormente, con la llegada de El Niño, la picnoclina se profundizó durante 2015 y alcanzó su máximo de profundidad en 2016, con un valor similar al observado en 2007 ( $\sim 80 \mathrm{~m}$, primer máximo de la serie de tiempo). Aunque en la zona costera los cambios no fueron tan marcados comparados con los de la zona oceánica, cabe destacar la leve profundización de la picnoclina a partir de la intrusión de agua subártica en 2002 y a partir de 2012 hasta 2016, bajo la influencia de "The Warm Blob" y El Niño.

Los índices de estratificación $\Phi_{100}$ y $\Phi_{200}$ presentaron una variación similar en ambas zonas (Fig. 2e, f). En las series de tiempo para ambos índices sobresalen el aumento en la estratificación de la columna de agua durante la intrusión de agua subártica $\left(\Phi_{100} \sim 150 \mathrm{~J} \cdot \mathrm{m}^{-3}\right.$ en ambas zonas; $\Phi_{200} \sim 450 \mathrm{~J} \cdot \mathrm{m}^{-3}$ y $\Phi_{200} \sim 350 \mathrm{~J} \cdot \mathrm{m}^{-3}$ en la zona oceánica y costera, respectivamente) y el máximo observado durante 2015 después de la ocurrencia de "The Warm Blob" y la llegada de El Niño 2015-2016 $\left(\Phi_{100} \sim 225 \mathrm{~J} \cdot \mathrm{m}^{-3}\right.$ y $\Phi_{200}>500 \mathrm{~J} \cdot \mathrm{m}^{-3}$ en ambas zonas).

\section{Discusión}

De las variables analizadas, la biomasa de fitoplancton fue la que mejor reprodujo la variabilidad interanual debida a diferentes eventos que influenciaron el océano frente a la zona norte de Baja California. Nuestra hipótesis es que los periodos de alta estratificación causan la reducción en la biomasa del fitoplancton y afectan la foto-fisiología del 
The largest reduction in PP rates was observed during El Niño 2015-2016, despite the fact that stratification in the northern region off Baja California was the highest in the past 19 years. This may have occurred because, for the first time in history, there was a warm event that preceded an El Niño event (Jacox et al. 2016). The marked deepening of the pycnocline and of the mixed layer during "The warm Blob", coupled with the high water column stratification during El Niño 2015 (Figs. 2d-f), probably limited the availability of nutrients in the euphotic zone, leading to a decrease in phytoplankton growth rates and hence resulted in lower PP. In addition, the warming of the upper ocean layer $(0-100 \mathrm{~m})$ prompted by both events limited phytoplankton photosynthesis.

The depth of the pycnocline and the mixed layer showed greater variability in the oceanic area. This may be due to the prevalence of remote forcings over local forcings (Durazo et al. 2017). In general, in addition to remote signals, the coastal environment is also influenced by local forcings that can mitigate temporal variability. Therefore, $Z_{P y c}$ and MLD in the oceanic area best represent the interannual variability in the northern zone off Baja California.

In order to assess the relationship between the variability of phytoplankton production and stratification, GAMs were used to determine the relationship between 2 of the characteristic phytoplankton photosynthetic parameters, $\alpha^{B}$ and $P_{m}^{B}$, and the $\Phi_{100}$ stratification index (Fig. 3). $P_{m}^{B}$ is associated with enzymatic photosynthetic processes and depends on factors such as temperature (Eppley 1972), nutrient concentration (Glover 1980) and cell size (Malone 1980), among others. The $\alpha^{B}$ parameter depends on cell size (Taguchi 1981), pigment composition (Handall 1970), and nutrient availability (Platt et al. 1992). In this work, $\alpha^{B}$ showed high values when the water column was more mixed (low $\Phi_{100}$ values, Fig. 3a), whereas $P_{m}^{B}$ increased along with stratification (increase in $\Phi_{100}$, Fig. 3b). These relations explained the interannual variations in PP in terms of phytoplankton physiology in the northern region off Baja California.

The above results suggest that PP rates are influenced by stratified environments (Huisman 1999, Diehl et al. 2002). This relationship is supported by the analysis with GAMs, revealing that high stratification is related to peak maximum photosynthetic rates. In addition, it is supported by the temporal variation in the $P_{m}^{B}$ parameter, which peaked in 2003, when increased stratification and PP co-occurred (Fig. 4a). The increased $P_{m}^{B}$ could be related to the photoacclimation of small phytoplankton cells-such as cyanophyta and prochlorophyta-at high irradiance levels, as suggested by the results of Geider et al. (1993); these authros observed changes in $P_{m}^{B}$ between phytoplankton of different cell sizes, with low $P_{m}^{B}$ in large diatoms at the same growth irradiance. On the other hand, $\alpha^{B}$ was higher in turbulent environments (well-mixed water column, less stratification), likely due to the presence of large phytoplankton cells that were photoacclimated at low fitoplancton (disminución de $\alpha^{B}$, incremento de $P_{m}^{B}$ ), y estos cambios inciden en las variaciones de la PP.

La estratificación se relacionó con los declives e incrementos de producción y biomasa del fitoplancton durante la intrusión de agua subártica, La Niña 2008 y el calentamiento del océano por "The Warm Blob” y El Niño 2015-2016. Durante los periodos cálidos y la intrusión de agua subártica, se observó alta estratificación de la columna de agua en conjunto con la reducción en la MLD y $Z_{P y c}$. En una columna de agua poco mezclada, el fitoplancton puede permanecer en la parte superior bien iluminada durante el tiempo suficiente para mantener una población (Huisman 1999). En contraste, cuando la columna de agua está bien mezclada, el fitoplancton es transportado a través de esta $\mathrm{y}$, con el tiempo, cada microorganismo experimenta la intensidad de luz promediada en profundidad, la cual decrece según la MLD. En consecuencia, la PP promediada en profundidad disminuye con el aumento de la profundidad de la columna de agua (Huisman 1999, Diehl et al. 2002). Adicionalmente, la MLD y la intensidad de mezcla están relacionadas con la acumulación de biomasa por medio de la pérdida de células fitoplanctónicas por sedimentación (Jäger et al. 2008). La probabilidad de que un organismo fitoplanctónico o una colonia se hunda fuera de la zona eufótica disminuye con el incremento de la intensidad de la mezcla (Huisman et al. 2004). Lo anterior, se debe a que la mezcla turbulenta dispersa al fitoplancton en la columna de agua y, por lo tanto, contrarresta parcialmente la sedimentación. En general, las pérdidas por hundimiento afectan principalmente a los organismos que se hunden rápidamente (e.g, las diatomeas) en columnas de agua poco profundas y débilmente mezcladas (Diehl et al. 2002). En resumen, una columna de agua débilmente mezclada (alta estratificación) favorece las tasas de PP, pero restringe la acumulación de biomasa, tal y como se observó durante el periodo de intrusión de agua subártica de 2003 a 2005 y durante "The Warm Blob" en el periodo 2013-2014 (Fig. 2).

La reducción más alta en las tasas de PP se observó durante El Niño 2015-2016, a pesar de que el océano en la zona norte frente a Baja California presentó la estratificación más alta de los últimos 19 años. Esto puede deberse a que, por primera vez en la historia, se registró un evento cálido que antecede la ocurrencia de un evento de El Niño (Jacox et al. 2016). La elevada profundización de la picnoclina y de la capa de mezcla durante "The Warm Blob", sumada a la alta estratificación de la columna de agua durante El Niño 2015 (Fig. 2d-f), probablemente limitaron la disponibilidad de nutrientes en la zona eufótica y originó una disminución en las tasas de crecimiento y, por ende, en la PP del fitoplancton. Adicionalmente, el calentamiento de la capa superior del océano $(0-100 \mathrm{~m})$ propiciado por ambos eventos limitó la realización de la fotosíntesis por parte del fitoplancton.

La profundidad de la picnoclina y la capa de mezcla presentaron mayor variabilidad en la zona oceánica. Esto puede deberse a la importancia relativa de los forzamientos remotos 


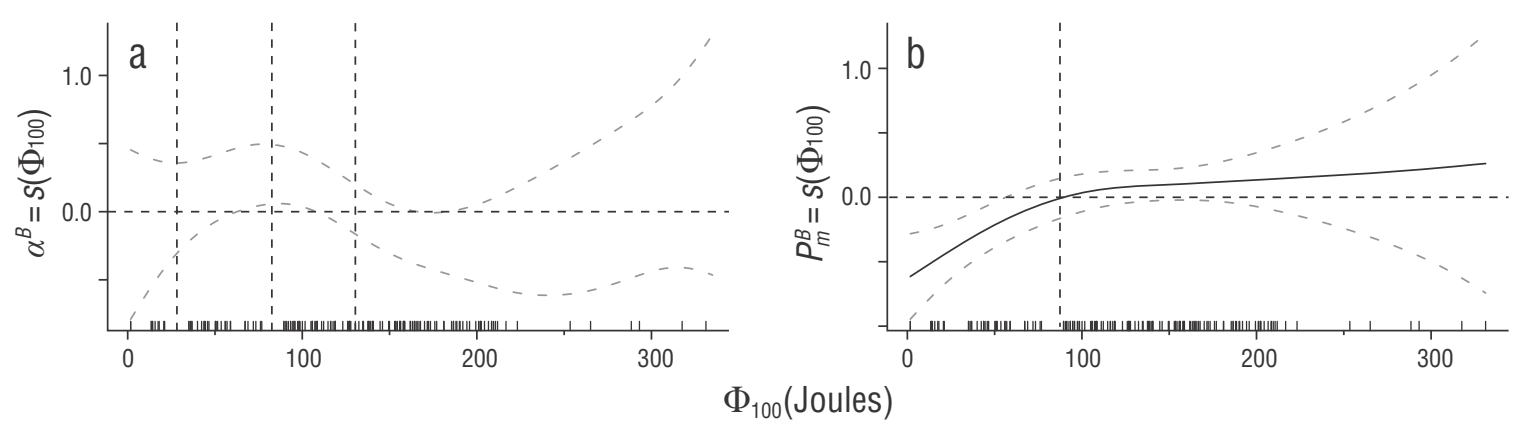

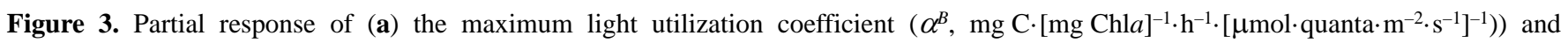
(b) maximum photosynthetic rate $\left(P_{m}^{B}, \mathrm{mg} \mathrm{C} \cdot[\mathrm{m} \mathrm{Chla} \cdot \mathrm{h}]^{-1}\right)$ to the water column stratification parameter at $100 \mathrm{~m} \mathrm{depth}\left(\Phi_{100}\right.$, a and $\left.\mathbf{b}\right)$, as defined by the generalized additive models (GAMs). The smoothing functions $(S)$ are represented as solid lines and the $95 \%$ confidence intervals as dashed lines. Rugged lines on the $x$-axes represent the observed $\Phi_{100}$ values. The $y$-axis labels show the GAM smoothing function. The vertical dashed lines represent the threshold values of the change from positive to negative (or viceversa) influence of the predictor variable $\left(\Phi_{100}\right)$ on the response variable $\left(\alpha^{B}, P_{m}^{B}\right)$.

Figura 3. Respuesta parcial de (a) el coeficiente de máxima utilización de luz $\left.\left(\alpha^{B}, \mathrm{mg} \mathrm{C} \cdot[\mathrm{mg} \mathrm{Chla}]^{-1} \cdot \mathrm{h}^{-1} \cdot\left[\mu \mathrm{mol} \cdot \mathrm{cuanta} \cdot \mathrm{m}^{-2} \cdot \mathrm{s}^{-1}\right]^{-1}\right)\right)$ y $(\mathbf{b})$ tasa fotosintética máxima ( $\left.P_{m}^{B}, \mathrm{mg} \mathrm{C} \cdot[\mathrm{m} \mathrm{Chla} \cdot \mathrm{h}]^{-1}\right)$ al parámetro de estratificación estimado para los primeros $100 \mathrm{~m}$ de profundidad $\left(\Phi_{100}\right.$, a y b), según los modelos aditivos generalizados (GAM). Las funciones suavizadas $(S)$ están representadas por líneas solidas, y el intervalo de confianza (95 \%) por líneas punteadas. Las líneas en el eje $x$ representan los valores observados para $\Phi_{100}$. Las leyendas en el eje $y$ muestran la función suavizada GAM. Las líneas punteadas verticales representan los umbrales de cambio de influencia positiva a negativa (o viceversa) de la variable predictora $\left(\Phi_{100}\right)$ sobre la variable respuesta $\left(\alpha^{B}, P_{m}^{B}\right)$.

irradiances, since they are displaced throughout the water column. These differences in magnitude due to phytoplankton size had been previously reported for the same study area by Gonzalez-Morales et al. (1993). Sosa-Avalos et al. (forthcoming 2017 Sep) found that the variability in $\alpha^{B}$ resulted from spatial and temporal changes in phytoplankton populations, which were dominated mostly by diatoms and dinoflagellates during spring. It is precisely at this time of the year when the water column is poorly stratified due to the presence of more intense winds and coastal upwelling events (Durazo 2015). This was observed in 2007, the year that showed poor stratification coupled with maximum PP rates, an increase in biomass, and the highest $\alpha^{B}$ value in the time series (Figs. 2 y 4b). Therefore, high $\alpha^{B}$ in periods of reduced stratification suggests the presence of large phytoplankton species, while high $P_{m}^{B}$ in periods of marked stratification could be related to the presence of smaller phytoplankton species.

The results of this study support the conclusion that the periods of strongest water column stratification were the subarctic water intrusion from 2002 to 2006 and El Niño 2015-2016, which resulted in the greatest decline in phytoplankton biomass (in both periods) and PP (during El Niño 2015-2016) in the northern zone off Baja California. The photosynthetic parameters $\alpha^{B}$ and $P_{m}^{B}$ associated with phytoplankton photophysiology explained the variations in PP in relation to the stratification of the water column. The time series and the analysis presented here for $\mathrm{L} 100_{\text {IMEC }}$ will serve as indicators of the physical processes that occur off the peninsula and their implications for phytoplankton. These sobre los forzamientos locales (Durazo et al. 2017). De manera general, el ambiente costero recibe, además de señales remotas, la influencia de forzamientos de escala local que pueden reducir la variabilidad temporal. Por lo tanto, la $Z_{P y c} \mathrm{y}$ la MLD en la zona oceánica representan mejor la variabilidad interanual en la zona norte frente a Baja California.

Con el fin de evaluar la relación entre la variabilidad de la producción del fitoplancton y la estratificación, se utilizaron los GAM para determinar la relación entre 2 de los parámetros fotosintéticos característicos del fitoplancton, $\alpha^{B}$ y $P_{m}^{B}$, con el índice de estratificación $\Phi_{100}$ (Fig. 3). El $P_{m}^{B}$ está relacionado con procesos enzimáticos de la fotosíntesis y depende de factores tales como temperatura (Eppley 1972), concentración de nutrientes (Glover 1980), tamaño de células (Malone 1980), entre otros. El $\alpha^{B}$, depende del tamaño celular (Taguchi 1981), la composición de pigmentos (Handall 1970) y la disponibilidad de nutrientes (Platt et al. 1992). En este trabajo, el $\alpha^{B}$ mostró valores altos cuando la columna de agua estaba más mezclada (bajos valores de $\Phi_{100}$, Fig. 3a), mientras que el $P_{m}^{B}$ aumentó con el incremento en la estratificación (aumento en $\Phi 100$, Fig. 3b). Estas relaciones explicaron las variaciones interanuales de la PP en términos de la fisiología del fitoplancton en la región norte frente a Baja California.

Los resultados anteriores sugieren que las tasas de PP se ven favorecidas por ambientes estratificados (Huisman 1999, Diehl et al. 2002). Esta relación está sustentada por el análisis de los GAM, donde se observó que las estratificaciones altas están relacionadas con las mayores $P_{m}^{B}$. Así mismo, está sustentada en la variación temporal del parámetro $P_{m}^{B}$, el cual 

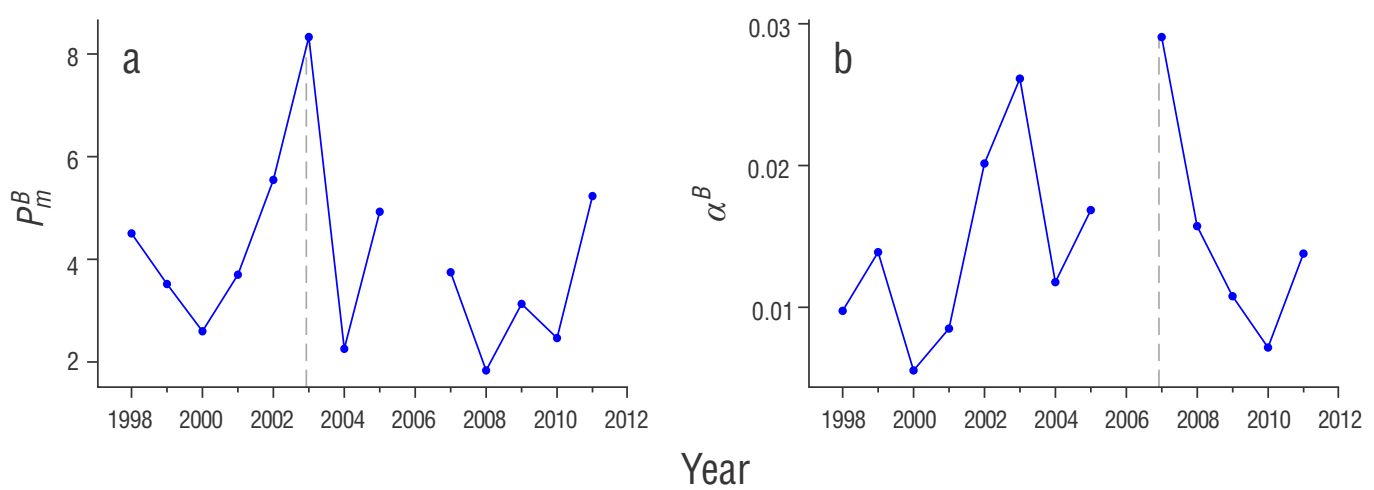

Figure 4. Time series for the average (a) maximum photosynthetic rates $\left(P_{m}^{B}, \mathrm{mg} \mathrm{C} \cdot[\mathrm{m} \mathrm{Chla \cdot h}]^{-1}\right)$ and $(\mathbf{b})$ the maximum light utilization coefficient $\left(\alpha^{B}\right.$, mg C $\left.\cdot[\mathrm{mg} \mathrm{Chla}]^{-1} \cdot \mathrm{h}^{-1} \cdot\left[\mu \mathrm{mol} \cdot \text { quanta } \cdot \mathrm{m}^{-2} \cdot \mathrm{s}^{-1}\right]^{-1}\right)$ at the oceanic stations of the IMECOCAL program. Dashed lines indicate the peak $P_{m}^{B}$ and $\alpha^{B}$ values of the time series.

Figure 4. Serie de tiempo para el promedio de (a) la tasa fotosintética máxima $\left(P_{m}^{B}, \mathrm{mg} C \cdot[\mathrm{mg} C h l a \cdot h]^{-1}\right)$ y $(\mathbf{b})$ el coeficiente de máxima utilización de luz $\left.\left(\alpha^{B} \text {, mg C·[mg Chla }\right]^{-1} \cdot \mathrm{h}^{-1} \cdot\left[\mu \mathrm{mol} \cdot \text { cuanta } \cdot \mathrm{m}^{-2} \cdot \mathrm{s}^{-1}\right]^{-1}\right)$ en las estaciones oceánicas del programa IMECOCAL. Las líneas punteadas indican los valores pico de $P_{m}^{B}$ y $\alpha^{B}$ de la serie de tiempo.

indicators could be extrapolated to other IMECOCAL areas to explain the annual and interannual variability of phytoplankton biomass and PP.

\section{ACKNOWLEDGMENTS}

We wish to express our very special gratitude to Gilberto Gaxiola-Castro† (RIP), who was a collaborator, teacher, and friend of the co-authors of this work. We appreciate all the knowledge provided and his influence on our formation as scientists. We will always remember him as a great person and researcher, and his presence will remain alive in our hearts. This work was funded by the National Council for Science and Technology (CONACYT, Mexico) (projects no. 255602 and 254745). CICESE provided assistance during vessel cruises. EGO is grateful for the scholarship (no. 271663) from CONACYT for postgraduate studies. RD and RSA have been awarded grants by the National System of Researchers (Mexico). We also thank the IMECOCAL program for the efforts made throughout 20 years of systematic monitoring off Baja California, as well as to all the people involved in the oceanographic cruises conducted as part of this program. María Elena Sánchez-Salazar translated the manuscript into English.

\section{REFERENCES}

Behrenfeld MJ, Falkowski PG. 1997. A consumer's guide to phytoplankton primary productivity models. Limnol. Oceanogr. 42(7): 1479-1491. http://dx.doi.org/10.4319/lo.1997.42.7.1479

Behrenfeld MJ, Boss ES. 2014. Resurrecting the ecological underpinnings of ocean plankton blooms. Ann. Rev. Mar. Sci. 6: 167-194.

http://dx.doi.org/10.1146/annurev-marine-052913-021325 fue máximo durante 2003, año en el cual ocurrió un aumento en la estratificación y se observó el incremento en la PP (Fig. 4a). El incremento de $P_{m}^{B}$ podría estar relacionado con la fotoaclimatación a altas irradiancias de pequeñas células de fitoplancton, como cianofitas y proclorofitas, tal como lo sugieren los resultados de Geider et al. (1993); estos autores observaron cambios de $P_{m}^{B}$ entre células de fitoplancton de diferente tamaño, con bajas $P_{m}^{B}$ en diatomeas grandes a la misma irradiancia de crecimiento. Por su parte, $\alpha^{B}$ fue más alta en ambientes turbulentos (columna de agua bien mezclada, menor estratificación), posiblemente debido a la presencia de grandes células de fitoplancton que estuvieron fotoaclimatadas a bajas irradiancias, ya que son desplazadas a través de la columna de agua. Estas diferencias en magnitud debido al tamaño del fitoplancton, han sido reportadas previamente para la misma área de estudio por GonzalezMorales et al. (1993). Sosa-Avalos et al. (a publicarse en 2017 Sep) encontraron que la variabilidad de $\alpha^{B}$ fue resultado de cambios espaciales y temporales de las poblaciones de fitoplancton, que fueron dominadas principalmente por diatomeas y dinoflagelados durante primavera. Es precisamente en esta época del año cuando hay menos estratificación en la columna de agua, debido a la presencia de vientos y surgencias costeras más intensas (Durazo 2015). Lo anterior se observó durante 2007, año que presentó baja estratificación, bajas tasas máximas de PP, un aumento en la biomasa y el valor máximo de $\alpha^{B}$ en la serie de tiempo (Figs. 2 y 4b). Por lo tanto, los $\alpha^{B}$ altos en periodos de menor estratificación sugieren la presencia de fitoplancton de mayor tamaño, mientras que $P_{m}^{B}$ altas en periodos de mayor estratificación estarían relacionados con la presencia de células más pequeñas.

A través de este estudio se concluye que los periodos de mayor estratificación en la columna de agua fueron la 
Daly KL, Smith WO. 1993. Physical-biological interactions influencing marine plankton production. Annu. Rev. Ecol. Syst. 24: 555-585.

http://dx.doi.org/10.1146/annurev.es.24.110193.003011

Diehl S, Berger S, Ptacnik R, Wild A. 2002. Phytoplankton, light, and nutrients in a gradient of mixing depths: Field experiments. Ecology 83(2): 399-411. http://dx.doi.org/10.2307/2680023

Durazo R. 2015. Seasonality of the transitional region of the California Current System off Baja California. J. Geophys. Res. Ocean. 120(2): 1173-1196. http://dx.doi.org/10.1002/2014JC010405

Durazo R. 2009. Climate and upper ocean variability off Baja California, Mexico: 1997-2008. Prog. Oceanogr. 83(1-4): 361-368. http://dx.doi.org/10.1016/j.pocean.2009.07.043

Durazo R, Baumgartner TR. 2002. Evolution of oceanographic conditions off Baja California: 1997-1999. Prog. Oceanogr. 54(1-4): 7-31. http://dx.doi.org/10.1016/S0079-6611(02)00041-1

Durazo R, Castro R, Miranda LE, Delgadillo-Hinojosa F. 2017. Anomalous hydrographic conditions off the northwestern Baja California Peninsula during 2014-2016. Cienc. Mar. 43(2): 81-92. http://dx.doi.org/10.7773/cm.v43i2.2754

Eppley RW. 1972. Temperature and phytoplankton growth in the sea. Fish. Bull. 70: 1063-1085.

Espinosa-Carreón TL, Gaxiola-Castro G, Durazo R, De la CruzOrozco ME, Norzagaray-Campos M, Solana-Arellano E. 2015. Influence of anomalous subarctic water intrusion on phytoplankton production off Baja California. Cont. Shelf Res. 92: 108-121. http://dx.doi.org/10.1016/j.csr.2014.10.003

Espinosa-Carreon TL, Strub PT, Beier E, Ocampo-Torres F, Gaxiola-Castro G. 2004. Seasonal and interannual variability of satellite-derived chlorophyll pigment, surface height, and temperature off Baja California. J. Geophys. Res. 109(C3): $1-20$.

http://dx.doi.org/10.1029/2003JC002105

Fiedler PC, Mendelssohn R, Palacios DM, Bograd SJ. 2013. Pycnocline variations in the eastern tropical and North Pacific, 1958-2008. J. Clim. 26(2): 583-599. http://dx.doi.org/10.1175/JCLI-D-11-00728.1

Gaxiola-Castro G, Lavaniegos BE, Martínez A, Castro R, EspinosaCarreón L. 2010. Pelagic ecosystem response to climate variability in the Pacific Ocean off Baja California, in: Simard, SW, Austin, ME. (Eds.), Climate Change and Variability. Sciyo, pp. 163-182. http://dx.doi.org/10.5772/9807

Gaxiola-Castro G, Durazo R, Lavaniegos B, De La Cruz-Orozco ME, Millán-Núñez E, Soto-Mardones L, Cepeda-Morales J. 2008. Pelagic ecosystem response to interannual variability off Baja California $=$ Respuesta del ecosistema pelágico a la variabilidad interanual del océano frente a Baja California. Cienc. Mar. 34(2): 263-270.

Gaxiola-Castro G, Cepeda-Morales J, Nájera-Martínez S, EspinosaCarreón TL, De la Cruz-Orozco ME, Sosa-Avalos R, AguirreHernández E, Cantú-Ontiveros J. 2010. Producción y biomasa del fitoplancton. In: Gaxiola-Castro G, Durazo R. (eds.), Dinámica del ecosistema pelágico frente a Baja California 1997-2007. Secretaría de Medio Ambiente y Recursos Naturales, Mexico, pp. 59-86.

Geider RJ, La Roche J, Greene RM, Olaizola M. 1993. Response of the photosynthetic apparatus of phaeodactylum tricornutum (Bacillariophyceae) to nitrate, phosphate, or iron starvation. J. Phycol. 29(6): 755-766.

http://dx.doi.org/10.1111/j.0022-3646.1993.00755.x intrusión de agua subártica 2002-2007 y El Niño 2015-2016, los cuales trajeron como consecuencia el mayor declive en la biomasa del fitoplancton (en ambos periodos) y de PP (durante El Niño 2015-2016) en la zona norte frente a Baja California. Los parámetros fotosintéticos $\alpha^{B}$ y $P_{m}^{B}$ relacionados con la foto-fisiología del fitoplancton explicaron las variaciones en la PP en relación con la estratificación de la columna de agua. Las series de tiempo y el análisis presentado aquí para la $\mathrm{L} 100_{\mathrm{IMEC}}$ servirán como indicadores de los procesos físicos que ocurren frente a la península y sus consecuencias para el fitoplancton, los cuales pueden ser extrapolados hacia otras zonas del IMECOCAL para explicar la variabilidad anual e interanual de la biomasa y PP del fitoplancton.

\section{AgRAdECIMIENTOS}

Queremos dar un agradecimiento muy especial a Gilberto Gaxiola-Castro $^{\dagger}$ (QEPD), quien fue colaborador, maestro y amigo de los coautores de este trabajo. Agradecemos todos los conocimientos brindados y su influencia en nuestra formación como científicos. Siempre lo recordaremos como una gran persona e investigador, y su presencia seguirá viva en nuestros corazones. Este trabajo fue financiado por el Consejo Nacional de Ciencia y Tecnología (CONACYT, México) a través de los proyectos 255602 y 254745 . CICESE otorgó facilidades para el tiempo de barco. EGO agradece la beca no. 271663 otorgada por el CONACYT para estudios de posgrado. RD y RSA son becarios del Sistema Nacional de Investigadores. Agradecemos al programa IMECOCAL por el esfuerzo realizado en 20 años de monitoreo sistemático frente a Baja California, así como también a todas las personas involucradas en los cruceros oceanográficos que fueron llevados a cabo como parte de este programa. Este manuscrito fue traducido al inglés por María Elena SánchezSalazar.

Glover HE. 1980. Assimilation numbers in cultures of marine phytoplankton. J. Plankton Res. 2(1): 69-79. http://dx.doi.org/10.1093/plankt/2.1.69

Gómez-Ocampo E, Gaxiola-Castro G, Durazo R, Beier E. 2017. Effects of the 2013-2016 warm anomalies on the California Current phytoplankton. Deep Sea Res. Part II Top. Stud. Oceanogr. accepted. http://dx.doi.org/10.1016/j.dsr2.2017.01.005

Gonzalez-Morales AT, Gaxiola-Castro G, Lara-Lara JR 1993. Daily Photosynthetic Parameters and Biomass from Size-Fractionated Phytoplankton off Baja California. Estuar. Coast. Shelf Sci. 36(2): 147-158.

http://dx.doi.org/10.1006/ecss.1993.1010

Handall P. 1970. The photosynthetic apparatus of microalgac and its adaptation to environmental factors. In: Halldal, PL (ed.), Photobiology of Micro-Organisms. Wiley-Interscience, pp. 17-55.

Hastie TJ, Tibshirani R. 1986. Generalized Additive Models: Some applications. J. of the Am. Statistic. Assoc. 82: 371-386. http://dx.doi.org/10.1080/01621459.1987.10478440. 
Holm-Hansen O, Lorenzen CJ, Holmes RW, Strickland JDH. 1965. Fluorometric Determination of Chlorophyll. ICES J. Mar. Sci. 30(1): 3-15.

http://dx.doi.org/10.1093/icesjms/30.1.3

Huisman J. 1999. Population Dynamics of Light-Limited Phytoplankton: Microcosm Experiments. Ecology 80(1): 202-210. http://dx.doi.org/10.2307/176990

Huisman J, Sharples J, Stroom JM, Visser PM, Kardinaal WEA, Verspagen JMH, Sommeijer B. 2004. Changes in turbulent mixing shift competition for light between phytoplankton species. Ecology 85(11): 2960-2970. http://dx.doi.org/10.1890/03-0763

Jacox MG, Hazen EL, Zaba KD, Rudnick DL, Edwards CA, Moore AM, Bograd SJ. 2016. Impacts of the 2015-2016 El Niño on the California Current System: Early assessment and comparison to past events. Geophys. Res. Lett. 43(13): 7072-7080. http://dx.doi.org/10.1002/2016GL069716

Jäger CG, Diehl S, Schmidt GM. 2008. Influence of water-column depth and mixing on phytoplankton biomass, community composition, and nutrients. Limnol. Oceanogr. 53(6): 2361-2373. http://dx.doi.org/10.4319/lo.2008.53.6.2361

Jassby AD, Platt T. 1976. Mathematical formulation of the relationship between photosynthesis and light for phytoplankton. Limnol. Ocean. 21: 540-547.

Jeronimo G, Gomez-Valdes J. 2010. Mixed layer depth variability in the tropical boundary of the California Current, 1997-2007. J. Geophys. Res. Ocean. 115(C5). http://dx.doi.org/10.1029/2009JC005457

Kara AB, Rochford PA, Hurlburt HE. 2000. An optimal definition for ocean mixed layer depth. J. Geophys. Res. 105(C7): 16803-16821. http://dx.doi.org/10.1029/2000JC900072

Lavaniegos BE. 2017. Changes in composition of summer hyperiid amphipods from a subtropical region of the California current during 2002-2008. J. Mar. Syst. 165:13-26.

http://dx.doi.org/10.1016/j.jmarsys.2016.09.001

Lavaniegos BE, Jiménez-Pérez LC, Gaxiola-Castro G. 2002. Plankton response to El Niño 1997-1998 and La Niña 1999 in the southern region of the California Current. Prog. Oceanogr. 54(1-4): 33-58.

http://dx.doi.org/10.1016/S0079-6611(02)00042-3

Lavaniegos BE, Molina-González O, Murcia-Riaño M. 2015. Zooplankton functional groups from the California current and climate variability during 1997-2013. CICIMAR Oceánides 30(1): 45-62.

Linacre L, Durazo R, Hernández-Ayón JM, Delgadillo-Hinojosa F, Cervantes-Díaz G, Lara-Lara JR, Camacho-Ibar V, SiqueirosValencia A, Bazán-Guzmán C. 2010. Temporal variability of the physical and chemical water characteristics at a coastal monitoring observatory: Station ENSENADA. Cont. Shelf Res. 30(16): 1730-1742. http://dx.doi.org/10.1016/j.csr.2010.07.011
Malone TC. 1980. Algal size. In: Morris ZI (ed.), Physiological Ecology of Phytoplankton. Blackwell, pp. 433-464.

Marcel B, Morel A, Gagnon R. 1994. An incubator designed for extensive and sensitive measurements of phytoplankton photosynthetic parameters. Limnol. Oceanogr. 39(3): 694-702. http://dx.doi.org/10.4319/lo.1994.39.3.0694

Marra J. 1978. Phytoplankton photosynthetic response to vertical movement in a mixed layer. Mar. Biol. 46(3): 203-208. http://dx.doi.org/10.1007/BF00390681

Martinez-Fuentes LM, Gaxiola-Castro G, Gómez-Ocampo E, Kahru M. 2016. Effects of interannual events (1997-2012) on the hydrography and phytoplankton biomass of Sebastián Vizcaíno Bay = Efectos de eventos interanuales (1997-2012) sobre la variabilidad hidrográfica y biomasa del fitoplancton en bahía Sebastián Vizcaíno. Cienc. Mar. 42(2): 81-97. http://dx.doi.org/10.7773/cm.v42i2.2626

Martínez-Gaxiola M, Durazo R, Gaxiola-Castro G. 2010. Influence of the geostrophic transport of phosphates on primary production off Baja California $($ Mexico $)=$ Aporte del transporte geostrófico de fosfatos a la producción primaria frente a Baja California. Ciencias Mar. 36(2): 135-145.

Platt T, Sathyendranath S, Ulloa O, Harrison WG, Hoepffner N, Goes J. 1992. Nutrient control of phytoplankton photosynthesis in the Western North Atlantic. Nature 356(6366): 229-231. http://dx.doi.org/10.1038/356229a0

Simpson JH, Bowers D. 1981. Models of stratification and frontal movement in shelf seas. Deep Sea Res. Part A. Oceanogr. Res. Pap. 28(7): 727-738. http://dx.doi.org/10.1016/0198-0149(81)90132-1

Sosa-Avalos R, Durazo R, Mitchell BG, Cepeda-Morales J, GaxiolaCastro G. Forthcoming 2017 Sep. Parámetros fotosintéticos frente a Baja California: una herramienta para estimar la producción primaria con datos de sensores remotos. Cienc. Mar.

Strickland JDH. 1965. Phytoplankton and marine primary production. Annu. Rev. Microbiol. 19: 127-162. http://dx.doi.org/10.1146/annurev.mi.19.100165.001015

Taguchi S. 1981. Seasonal studies of the dinoflagellate Ceratium longipes (Bailey) Gran in the Bedford Basin, Canada. J. Exp. Mar. Bio. Ecol. 55(2-3): 115-131. http://dx.doi.org/10.1016/0022-0981(81)90106-4

Trenberth KE, Large WG, Olson JG. 1990. The mean annual cycle in global ocean wind stress. J. Phys. Oceanogr. 20(11): 1742-1760. http://dx.doi.org/10.1175/15200485(1990)020<1742:TMACIG>2.0.CO;2

Wood AS, Wood MS, Wood S. 2015. Package “ mgcv ” [cited 28 june 2017]. Available from: https://cran.r-project.org/web/ packages/mgcv/mgcv.pdf.

Wood SN. 2006. Generalized Additive Models: an introduction with R. Chapman \& Hall/CRC, Boca Raton, FL.

Yentsch CS, Menzel DW. 1963. A method for the determination of phytoplankton chlorophyll and phaeophytin by fluorescence. Deep Sea Res. Oceanogr. Abstr. 10(3): 221-231. http://dx.doi.org/10.1016/0011-7471(63)90358-9

Received March 2017, accepted May 2017. 